\title{
Turkey's reaction to the coup in Egypt in comparison with the US and Israel
}

\section{Mehmet Yegin}

To cite this article: Mehmet Yegin (2016) Turkey's reaction to the coup in Egypt in comparison with the US and Israel, Journal of Balkan and Near Eastern Studies, 18:4, 407-421, DOI: 10.1080/19448953.2016.1196010

To link to this article: https://doi.org/10.1080/19448953.2016.1196010

曲 Published online: 05 Jul 2016.

Submit your article to this journal

Џll Article views: 206

Q View related articles ¿

View Crossmark data $₫$ 


\title{
Turkey's reaction to the coup in Egypt in comparison with the US and Israel
}

\author{
Mehmet Yegin \\ Department of Political Science and Public Administration, Bilkent University, Ankara, Turkey
}

\begin{abstract}
In this study, Turkey's reaction to the ousting of Mohammed Morsi in Egypt is studied in comparison with one regional and one global actor with a democratic regime. This study aimed to examine the dynamics of Turkey over-signalling negatively to the coup in comparison with Israeli and American reactions. In comparison with Turkey's reaction, the US shyly signalled positively in statements and used financial means against the coup hesitantly. Israel pursued a 'strategic silence' approach and eschewed signalling at all. It is seen that all three countries' motivations were dominantly material, and no country reacted with purely normative motivations. The US and Turkey applied a selective normative approach according to their material motivations. While Turkey focused on the illegitimacy of the coup, the US focused on the illiberal policies of Morsi whereas Israel openly avoided adopting a normative approach.
\end{abstract}

\section{Introduction}

A 'good coup' label or a 'bad coup' label is not determined solely according to whether the coup was intended to push a society towards democracy or autocracy. Occasionally the international actors do not respond, either positively or negatively, to certain coups due to their lack of interest. ${ }^{1}$ Egypt is the most populous Arab country with significant influence in the Middle East and it possesses strategic assets, primarily the Suez Canal. Thus, the coup against Mohammed Morsi in Egypt on 3 July 2013 may not be neglected like others. Since the coup overthrew a democratically elected administration, the reactions against coup have a normative aspect but the international actors did not automatically label the coup as 'bad coup'. Indeed, Egypt pushed actors like the United States (US) and the European Union (EU), as champions of democracy, to make hard choices, primarily in the labelling of the incident as a coup or not. Conversely, Turkey positioned itself as in strong opposition to the coup in Egypt and was, in fact, one of the most vocal countries against the coup. Not only in terms of statements, but also in actions, Turkey pushed hard for a reversal of the coup in Egypt. This approach by Turkey is unprecedented, yet its differentiation from the other actors is salient as well. In order to make better sense of Turkey's reaction, a comparative case analysis with two other democratic states seems necessary. In this article, the reactions 
of Turkey to the July 2013 coup in Egypt, in comparison with the US as a global actor and Israel as a regional democratic actor, will be examined based on motivations and signalling. In order to more effectively study the responses of these three countries, the framework of Shannon et al. in their article titled 'The international community's reaction to coups', one of the rare studies on the matter, will be applied in terms of these three states' reactions to the Egypt coup in order to evaluate the material and normative motivations and the way they signalled in response to the coup.

\section{External reactions to coups d'état}

\section{Reaction motivations of states}

Foreign responses to military coups originate from two types of motivations: the normative and the material. ${ }^{2}$ The normative motivation refers to protection of democracy against authoritarianism due to its normative value. Especially in the twentieth century, because of the increasing number of democratically ruled countries, democracy became a 'universal value' voiced louder than ever before. ${ }^{3}$ The second wave of democratization after the Second World War, and the third wave after the collapse of the Soviet Union, solidified this trend. ${ }^{4}$ Thus, 'democracy as an international norm is stronger today than ever' and that protecting and supporting democracy is becoming acknowledged by states as one of the foreign policy goals. ${ }^{5}$ Material motivations, on the other hand, are about economic and/or strategic security issues. The economic interests at stake may relate to trade agreements, oil supply, and major company investments in the country concerned. ${ }^{6}$ The strategic security interests may involve the alliance relations at stake or military base and facility usage agreements. Thus, the countries react to coups détat in order to protect their economic or strategic interests. The normative and material interests may motivate the states to respond to coups d'état either positively or negatively. According to the interests at stake, the states may react strongly or keep a low profile.

\section{Positive or negative signalling}

The foreign actors' positive or negative reactions to the coups 'have meaningful influences on the country's post-coup political trajectory. ${ }^{7}$ Since the post-coup leaders seek legitimacy, they need international support along with domestic blessing. Positive signals given by other states ease the transition process and help the coup leaders establish their authority. Negative signals, on the other hand, challenge the legitimacy of the new authority and encourage the domestic opposition to react against them. Indeed, even moderately negative reactions from an outside country decrease the lifetime of a coup-born regime and shorten their 'leader duration' significantly. ${ }^{8}$ In terms of reactions, the statements of high-level officials and direct actions of states are called signals. ${ }^{9}$ Signals enable the observers to deduce positive or negative responses. The normative and material motivations and capacity to influence the post-coup regime determine the states' decisions on signalling. In response to a new regime, states may decide to signal hostilely, positively and supportively, or avoid signalling at all. The minimum negative reaction to a coup d'état is denunciation of the illegal action and a call for the restoration of the former regime. ${ }^{10}$ In normative means, in order to protect democracy as a value, a quick and unequivocal public condemnation of the coup would be 
necessary. The presence of a strong condemnation of coups against democratically elected governments would change the calculations of future coup attempts. ${ }^{11}$

Negative signalling is not limited to public statements by state officials or political leaders. It may include economic and financial sanctions as well as sanctions targeting key individuals, using tactics such as visa restrictions and asset freezing. ${ }^{12}$ The effectiveness of economic sanctions is questioned, but such targeted sanctions are influential in the destabilization of targeted coup governments. ${ }^{13}$ For example, in response to the coup in Fiji in 2000, the Australian government implemented a trade boycott and employed a travel ban on coup leader George Speight that blocked his ability to contact his family. ${ }^{14}$ Fiji's experience in 2000 suggests possible success in using economic sanctions to restore democracy. The last resort when responding to a military coup is the use of force on behalf of the overthrown government. This response is the strongest that a country may decide to employ individually or within a collective international body. The US reaction to the coup in Haiti in 1991 is an important example. The US, under the United Nations Security Council Resolution 940 mandate, made a successful military intervention to restore the former leadership with a coalition of countries. ${ }^{15}$ Foreign states may also give supportive signals after a coup. Similar to negative signals, first, the state officials or political leaders may make public statements that either directly or indirectly legitimize the coup. For instance, the US supported the 2002 coup attempt against Hugo Chavez in Venezuela. The American administration avoided using the term 'coup' and, instead, deemed Chavez and his undemocratic practices blameworthy in regard to the developments. ${ }^{16}$

Statements that endorse the reasons behind the coup, or directly support the coup as a whole, increase the legitimacy of the post-coup regime. Beyond statements of support, countries often provide economic aid to the state after the coup. They may offer weapons as well as an increasing supply of other necessary goods. For instance, in exchange for its cooperation with the US to combat terrorism in Afghanistan, Pakistani coup-leader Pervez Musharraf received $\$ 10$ billion in financial and military aid until 2007 and the Bush administration committed to technology sharing and sales of F-16s. ${ }^{17}$ Using the framework provided above, the material and normative motivations will be examined within the states' responses in statements and symbolic actions regarding the legitimacy of the post-coup regime along with diplomatic, economic and financial measures when applicable.

\section{Road to coup d'état in Egypt}

After the ousting of Hosni Mubarak during the Arab uprisings, the Supreme Council of Armed Forces (SCAF) assumed power with the promise to carry authority to elected civilian leaders. SCAF could not meet the expectations of the Egyptians, and their mistakes caused them to lose credibility. They not only continued to push for police suppression to stop the protests but they also could not bring any change to the dire economic conditions, and this caused public calls for a civilian administration. ${ }^{18}$ As promised, the parliamentary and presidential elections were held and the Muslim Brotherhood (MB), with a strong, organized network throughout the country, did not have a real competitor. ${ }^{19}$ Thus, its Freedom and Justice Party (FJP) won 42 per cent of the votes in the Lower House, 58 per cent of the votes in the Upper House and finally 52 per cent of the votes in the presidential elections on 16-17 June 2012. ${ }^{20}$ The MB's candidate, Mohammed Morsi, was elected President. In the meantime, SCAF increased its power with seven major amendments in the constitution that 
'subordinated the president to military command', primarily via the authority of legislation and immunity from civilian oversight. ${ }^{21}$ One month later, SCAF members were replaced by a young generation of officers led by General Abd-el Fettah el-Sisi.

The new administration brought some changes to Egypt's foreign affairs but did not cause a major drift. The Morsi administration drew closer to Turkey and gave signals to balance Iran in Iraq and Syria along with Turkey. ${ }^{22}$ Morsi 'demonstrated more independence from the United States and Israel but maintained the peace treaty and sought to reassure foreign powers about continuity in core policy areas. ${ }^{23}$ The US administration welcomed their readiness to cooperate and decided to engage and invest in the MB both before and after the elections. ${ }^{24}$ However, after attacks on the US Embassies in Benghazi and Cairo on 11 September 2012, US President Barack Obama used a strong tone towards Egypt and stated: 'I don't think that we would consider them an ally. ${ }^{\text {'25 }}$ In domestic matters, the military managed to preserve its place and power in the Egyptian political and economic systems. ${ }^{26}$ Despite the dominance of the Egyptian military, President Morsi failed to form pacts with the secular and liberal groups within Egypt. His attempt to consolidate his position in a very short time, along with the new constitution and increasing number of Brotherhood members in state institutions, gave the impression of a power grab. ${ }^{27}$ Morsi was inexperienced at running a country and the political landscape was not providing chances to bring reforms. He could not deliver the expected economic changes in such a short time, and the everyday life of Egyptians was not improved. ${ }^{28}$ These problems brought public protests against Morsi and provided means for the military to intervene.

On 1 July 2013, el-Sisi gave an ultimatum to the government that asked for the 'fulfilment of people's demands' in 48 hours and asserted that otherwise the military would declare a roadmap for politics in Egypt. ${ }^{29}$ In response to the army's appeal Morsi rejected resignation and the call for elections, and denounced the Egyptian Army for making statements without consulting him. ${ }^{30}$ On 3 July 2013 the Egyptian army, under the leadership of General el-Sisi, declared the disbanding of the government and suspension of the constitution. In reaction to these developments, $\mathrm{MB}$ supporters went onto the streets for peaceful public protests. Nonetheless, the Morsi supporters at Rabaa al-Adawiyye Square were raided by the security forces and more than 1300 people were killed and nearly $3500 \mathrm{MB}$ members were arrested. ${ }^{31}$ The judge recommended that $683 \mathrm{MB}$ members be sentenced to death. Among those, the courts confirmed the death sentence for 183 members. ${ }^{32}$ One year later, in the presidential elections that took place on 26-28 May 2014, el-Sisi was elected as the new president of Egypt.

\section{Turkey's reaction to the coup: over-signalling for a lost bet}

Turkey had both material motivations in terms of losing a key ally in the region and normative motivations in its strong negative reaction to the coup d'état in Egypt. The country's signalling was packaged mainly within the framework of the normative approach that focused on the ballot box in terms of democracy and illegitimacy of a military overthrow. The Turkish government signalled negatively to the coup regime in exhaustive ways, including statements, diplomatic means, financial measures, protests and conferences. 


\section{Material and normative motivations}

The strategic loss for Turkey caused by the coup was one of the motivations behind Turkey's actions, as the country had been seeking ways to increase its influence in the Middle East. The leadership in Turkey was looking to the revolution in 2011 as a major opportunity to do just that. Indeed, the architect of Turkish Foreign Policy, Minister of Foreign Affairs Ahmet Davutoğlu, considered the uprisings a chance for Turkey to show its 'potential to contribute [to] the transformation of the international system. ${ }^{33}$ Having a similar ideological background to the ruling Justice and Development Party, Turkish leaders regarded the $\mathrm{MB}$ rule in Egypt as an opportunity. Along with this perspective, the Turkish government focused on the $\mathrm{MB}$ in relation to Egypt to the extent that it caused criticisms and alienation of the other political groups. ${ }^{34}$ The Turkish government had a new vision for the Middle East, and Egypt under Mohammed Morsi's rule was regarded as 'key ally'. ${ }^{35}$ Along with this vision, there was an attempt to develop a common approach on the Syrian crisis and the Mediterranean strategy, and to move together on the Palestinian-Israeli dispute. ${ }^{36}$

As a result, Turkey invested both politically and economically in the MB ruling Egypt before the coup. Turkey dispatched US $\$ 2$ billion as a direct loan and also provided training to counterparts on policing and party politics. ${ }^{37}$ Moreover, Turkey established the HighLevel Strategic Cooperation Council with Egypt and conducted military exercises in Turkish territorial waters in the Eastern Mediterranean. ${ }^{38}$ Turkey also increased its high-level visits to Cairo and signed 28 agreements with Egypt ${ }^{39}$ However, the coup détat stifled all of efforts to develop a 'strategic partnership' between Turkey and Egypt ${ }^{40}$ with a common identity of two ruling parties based on political Islam.

Turkey's focus on the MB backfired not only in losing all these political investments but also because of concerns caused by the coup's reflections on Turkey. These concerns related to the position of the ruling party vis-à-vis the military in Turkey and a possible triggering effect of the Egyptian coup in Turkey. Since the overthrow of Morsi was realized in tandem with the public protests, the Gezi protests in Turkey increased the concerns of the ruling party. ${ }^{41}$ As a reaction, the ruling party in Turkey took an offensive stance against the coup in Egypt. There are also claims that the ruling party might use the Egyptian coup as a way to delegitimize the Gezi movement and Turkish opposition ${ }^{42}$ as well as to commercialize the 'victimhood of the Muslim Brotherhood' to rally its supporters. ${ }^{43}$

The economic issues, compared with the strategic and political concerns, did not play as strong a role in motivating Turkey's responses. It is true that the trade volume between Turkey and Egypt increased threefold after the 2011 revolution and reached US $\$ 5$ billion in 2012. Further, there were nearly 300 Turkish investors with a US $\$ 2$ billion investment before the coup in Egypt. ${ }^{44}$ After the coup, the new administration declared that some trade agreements would not be renewed, ${ }^{45}$ but the el-Sisi administration did not bring major disruption to trade with Turkey. The Turkish administration was not expecting a significant economic loss or negative effect on Turkish investments. ${ }^{46}$ Thus, Turkey's reaction to the coup in Egypt did not primarily stem from its economic motivations.

Turkey had normative motivations in reacting to the removal of the Morsi government by the Egyptian military. The Turkish government was supporting the demands of the people in Arab streets and gave importance to the ballot box. According to Davutoglu, Turkey had an honourable position that favoured the masses against their authoritarian regime and sided with 'the leaders elected by the people. ${ }^{47}$ Nonetheless, some critiques highlighted 
the fact that the Turkish government was non-responsive to the Gezi Park protests and the protests in Egypt against Morsi's rule based on demands for 'pluralistic political order with unambiguous recognition and respect for diversity. ${ }^{48}$ Thus, it seems that the Turkish government had a normative motivation in terms of its minimal definition of democracy as free and fair elections, rather than a broader conceptualization with accountability and pluralism to achieve liberal democracy. ${ }^{49}$

\section{Over-signalling hostile}

Turkey gave strong negative signals to the post-coup military administration after the removal of Morsi. In terms of statements, Turkish high-level officials, primarily Prime Minister (PM) Tayyip Erdoğan and Minister of Foreign Affairs (MFA) Ahmet Davutoğlu, reacted negatively to the coup. Erdoğan's statement implies both the context and very meaning of the Turkish normative approach. He asserted that:

Egypt should read the recent history of Turkey.... Without exception every coup made in Turkey caused it to lose decades.... Unequivocally coups are bad and in the end coup makers are not remembered with respect ... in the end they [are] brought before the court even in their old age.... There is no rule other than the ballot box in democracy. And insulting the majority, insulting the preferences of the majority is also an attempt to destroy democracy. ${ }^{50}$

MFA Davutoglu also stated that 'the governments elected by [the] public should go with only the public decision, their overthrow by coup d'état is unacceptable. ${ }^{51}$ Thus, the Turkish government condemned the coup immediately and unequivocally. The Turkish administration also denounced both the domestic institutions of Egypt and international actors that gave support to the coup or avoided condemning it. The Turkish PM criticized the Egyptian military and the Sheik of el-Ezher University due to their support of el-Sisi; yet, these criticisms backfired and caused poor reactions among the Egyptians. ${ }^{52} \mathrm{PM}$ Erdoğan also called for western countries to react to the coup and for Egyptian security forces' violent crackdown on Morsi supporters, and asked the UNSC to convene immediately on the matter. ${ }^{53}$ The Turkish government also pushed international organizations diplomatically to react to the coup in Egypt. The EU and the Organization of Islamic Cooperation (OIC) were called to react and Turkey denounced both organizations when they did not respond positively to the call. ${ }^{54}$

The Turkish government employed diplomatic measures and financial sanctions as well. It recalled the Turkish Ambassador to Cairo, Hüseyin Avni Botsalı, for consultations. ${ }^{55}$ In financial terms, Turkey stopped the aid given to Egypt ${ }^{56}$ Later, the Secretary General of OIC, Ekmeleddin İhsanoğlu, was also accused of not raising his voice enough against the coup, and the Turkish government called on him to resign his post as a reaction to the organization's passivity. ${ }^{57}$ In Turkey, there were also protests and several international conferences were arranged that supported the Morsi administration and denounced the coup regime. Primarily, the ruling party's youth organization was active in protests against the coup in Egypt. Concerning the conferences, the first round was held in Istanbul on 10 July 2013 with the participation of MB members; the second round of conferences was held in Istanbul and Lahore on 28 September 2013. The second round of conferences discussed topics regarding the coup in Egypt and international responses to it. ${ }^{58}$ 


\section{Preserve good relations with those running Egypt: US shy positive signalling to coup in Egypt}

The US had both material and normative motivations in its reaction to the coup détat in Egypt. The material motivations suggested that the US should remain silent or even support the coup; however, the normative motivations pushed for the denouncement of the military overthrow of the government and the illiberal policies pursued by Morsi. In contrast to the Turkish approach, the US focused more on the illiberal policies of Morsi rather than the illegitimacy of the military overthrow. The US administration was divided-it tried to strike a balance by releasing neutral statements from the White House and positive signalling from the State Department.

\section{Material and normative motivations}

The US administration often regarded Egypt as 'too important to be strongly pressured.' ${ }^{9}$ The main reason behind this premise is that certain strategic issues have been addressed only with the cooperation of the ruling actors in Egypt. These issues may be itemized: continuation of Egyptian-Israeli peace, over-flight rights and access to the Suez Canal, and cooperation on counter-terrorism efforts. ${ }^{60}$ Egypt has also been a recipient of American aid for more than three decades, which could be regarded as a long-term investment for the US. ${ }^{61}$ Nonetheless, Egypt had alternatives to the aid provided by the US: Russian President Putin offered possible arms sale as a substitute for US supplies. ${ }^{62}$ Thus, strategic motivations for the American administration suggested a positive response to the coup.

The US also had security concerns, especially after the attacks to the American embassies in Cairo and Benghazi on 11 September 2012. These attacks, especially that in Benghazi, increased the security concerns since the attack resulted in the death of four embassy personnel, including Ambassador Christopher Stevens. ${ }^{63}$ The attacks were also regarded as a harbinger of the increasing potential of extremist terrorism in the region. ${ }^{64}$ Along with the attack, the assessment of Arab uprisings shifted from a democracy-based approach to more of a security-based one, and concerns regarding the threat of militant Islamism increased. ${ }^{65}$ Indeed, the US had long faced the dilemma of material and normative motivations in Egypt, since it had to decide between authoritarianism and religious extremism. ${ }^{66} \mathrm{In}$ this dilemma, the US approach was first to secure its strategic concerns by preserving good relations with whoever was running Egypt. ${ }^{67}$ Thus, under the condition of meeting strategic concerns, the possibility of having a democratic regime as a counterpart is welcomed. Nonetheless, the US administration was not in a position to pressurise any ruling actor in Egypt for the sake of democratic norms because of the concern of losing leverage. This approach may be generalized to US policy after the ousting of Mubarak. The US administration did not react strongly to the SCAF on the issues of foray within the promotion of democracy, NGOs, and incarceration of their personnel. ${ }^{68}$ The US administration welcomed free and fair elections in Egypt, but did not put pressure on Morsi in reaction to his restrictions on the media and failure to bring about an inclusive constitution. ${ }^{69}$ 


\section{Hesitant positive signalling}

In the US response to the coup, a positive tone was more dominant. In terms of statements, US President Barack Obama declared on 3 July 2013 that 'the United States does not support particular individuals or political parties but [is] ... committed to a democratic process', and he called the Egyptian military 'to move quickly and responsibly to return full authority back to a democratically elected civilian government. ${ }^{70}$ Along with this statement, Obama alluded to Morsi's presidency not being truly democratic and Obama did not directly refer to the restoration of Morsi's presidency. Obama also did not mention the illegitimacy of the coup. In contrast, Secretary of State John Kerry's statements were more supportive of the coup regime. Kerry announced US support for 'Egypt's transition to democracy' and referred to his statement in March 2013, before the coup, as evidence of continuity in the US position. ${ }^{71}$ Both his wording and his reiteration of the position in March suggest indifference to the military coup as a negative development. Deputy Secretary of State William Burns was even clearer-he suggested the coup provided 'another opportunity' and 'chance' to correct the mistakes of the past two years. ${ }^{72}$

The US administration refrained from using the term 'coup' to address the developments in Egypt and el-Sisi utilized this approach by the US to establish greater legitimacy. It is claimed that this avoidance was related to the status of the US aid given to Egypt. The US code bans provision of assistance to governments with elected leaders who are overthrown by a coup détat. ${ }^{73}$ By refraining from use of the term 'coup', the US administration also avoided cutting the aid given to Egypt after the coup. There are claims that the US avoided losing its leverage on the generals by keeping the flow of aid. ${ }^{74}$ Yet, Hamid and Mandaville suggested that US leverage over the post-coup leaders is not limited by foreign aid and that the decision to continue the aid is not due to 'a lack of leverage, but [because of] absence of political will to use it. ${ }^{75}$ After the coup, both Arab and Israeli lobbies worked hard in Washington to prevent aid cuts. ${ }^{76}$ Significantly, the Saudis provided an unconditional US\$12 billion financial aid to Egypt and pledged to substitute the US aid with a direct loan if it was suspended. ${ }^{77}$ The US delays in the delivery of F-16s, cancelling the military exercise, and, in the end, partially blocking US aid were only hindering the Egyptian military from stopping bloodshed. Indeed, these actions were far from convincing el-Sisi. ${ }^{78}$ Later, Secretary Kerry's visit to Egypt and assurance to his Egyptian counterparts that the 'aid issue is a small issue' stifled the US leverage over el-Sisi. ${ }^{79}$ Nearly one year later, the US resumed partially frozen military aid to Egypt and proceeded with the delivery of Apache helicopters. ${ }^{80}$

\section{Israeli reaction to the coup: strategic concerns and strategic silence}

The material motivations were quite strong, if not existential, in the Israeli response to the coup in Egypt. In contrast to Turkey, the coup was strongly in favour of Israel's interests and the Israeli decision-makers deliberately avoided a normative approach. Since strategic calculations indicated that silence would best serve Israeli interests, Israel avoided openly signalling positively or negatively, despite offering support through private back channels. 


\section{Material and normative motivations}

The Israeli administration was concerned that the Islamists winning the election would lead to the hijacking of Egypt and the establishment of an Islamist authoritarian system that can be summarized in the 'one vote, one man, one time' framework. ${ }^{81}$ In this vein, Israel regarded its European and American counterparts as 'naive' at best in their optimistic expectations for Arab uprisings to bring more plural and democratic outcomes. ${ }^{82}$ Despite the western tendency to regard these developments as parallel to 'Europe 1989', Israel regarded them as 'Tehran 1979'.83 The Israeli administration did not see the social unrest as ordinary people seeking democracy; instead, it saw Islamists seeking power. According to the Israeli authorities, the MB and Morsi 'were no paragons of democracy' and democracy could not be achieved without democrats. ${ }^{84}$ Thus, Israel avoided the normative approach. Israel's main concerns about the $\mathrm{MB}$ coming to power were related to the issues of the Israel-Egypt Peace Treaty, relations with Hamas and security in the Sinai Peninsula. ${ }^{85}$ The military coup in July 2013 not only ended these concerns but also changed the balance in favour of Israel on these issues.

In terms of the peace treaty, Israel had concerns about its annulment, or at least opening it for renegotiation. ${ }^{86}$ There were even concerns that, either with the influence of its revolutionary change or its transition to democracy, Egypt might declare war against Israel. ${ }^{87}$ Despite the limited possibility of such outcomes, the Israeli concerns were not totally delusional. According to a Pew Research Center polling report published on 25 April 2011, 54 per cent of Egyptians were in favour of annulment of the peace treaty in comparison with only 36 per cent favouring its continuity. ${ }^{88}$ Thus, the Israeli leadership did not want to deal with the Egyptian public because they were expecting any dealings would be in 'Palestinian coin. ${ }^{39}$ The coup in Egypt ended all Israel's concerns and assured it of the future of the peace treaty once el-Sisi honoured it publicly. ${ }^{90}$

Another security concern was the position of Hamas after the MB came to power in Egypt. Since Hamas is the Palestinian branch of the MB, an affinity with the new Egyptian government increased the concerns of Israel. The Israeli administration was anxious about the possibility of Egypt opening the Rafah border and officially recognizing Hamas. ${ }^{91}$ On the contrary, Morsi avoided openly supporting Hamas, and even put pressure on Hamas politically and economically. ${ }^{92}$ Nevertheless, even a ceasefire brokered by Morsi did not put an end to Israeli concerns. After the overthrow of Morsi, Egypt's position was fundamentally changed on Hamas. The military regime regarded Hamas as an offshoot of the MB, which it declared to be a terrorist organization. Thus, it cut the flow of materials through the Rafah border and tunnels and endorsed Palestinian Authority as the true representative of Palestine. ${ }^{93}$ There are even claims that Egypt is becoming tougher on Hamas than Israel, which concerned the Israeli side regarding Egypt's mediation role between Israel and Palestine. ${ }^{94}$

Israel's final concern was about the security of the Sinai Peninsula. The terrorist activities in Sinai were a major concern to Israel and the revolution caused fears that the Egyptian government would turn a blind eye or avoid cooperating with Israel to combat terrorism. There were even fears of Sinai's 'Somalization' along with concerns about naval security. ${ }^{95}$ The Morsi administration pursued a policy not very different from that of Mubarak, yet Morsi did not have strong control over the security forces on the ground. This problem also ended for Israel after the coup. In short, the strategic and security concerns of Israel regarding the 
peace deal, Hamas and Sinai increased with the MB rule, but these concerns were met with the ousting of Morsi and new leadership after the coup, which even went beyond Israeli expectations. Thus, Israel had strong material motivations to support the coup in Egypt.

\section{'Strategic silence' avoiding signalling}

Because of Israel's support and opposition, any matter in the Middle East can be quite controversial, so the Israeli authorities decided to remain silent on the coup. Despite the signals in favour of and against the coup in the region, Israel avoided making any comments. ${ }^{96}$ According to the Director of the Center for the Study of the Middle East and Islam, Mordechai Kedar:

You can do things, but do them under the water. Israel, by supporting explicitly the army, exposes itself to retaliation. Israel should have done things behind the scenes, under the surface, without being associated with any side of the Egyptian problem. ${ }^{97}$

Thus, along with the 'strategic silence' policy, Israeli officials did not publicly declare their preferences or support of any party in the developments in order to avoid accusations of interference. ${ }^{98}$ Nonetheless, avoiding making much noise, Israel diplomatically declared an offence in its allies' capitals to gain support for the Egyptian military after the coup. ${ }^{99}$ Thus, in action, Israel gave diplomatic support to the coup in Egypt and pursued active lobbying, primarily in Washington.

\section{Conclusion}

In examining Turkey, the United States and Israel's reactions to the ousting of Mohamed Morsi in Egypt, we see that all three countries' motivations were dominantly material, and no country reacted with pure, normative motivations. They reacted in line with their strategic, security and economic motivations. Indeed their normative approaches were in line with their material approaches. Thus, the US and Turkey applied a selective normative approach according to their material motivations. While Turkey focused on the illegitimacy of the coup, the US focused on the illiberal policies of Morsi after the coup. Israel openly avoided a normative approach. The influence of the reactions is not related to the frequency of signalling, rather it is related to the level of global/domestic influence on the target country. Turkey's response, despite over-signalling negatively to the coup, was not as influential as the US's shyly positive signalling. Because of this, Saudis and Israelis lobbied for influence in Washington. Additionally, refraining from signalling in response to a coup does not always indicate indifference and lack of interest. The coup in Egypt was regarded as existential for Israel and avoiding signalling was part of its strategic calculation. These findings indicate that either the decision-makers in Turkey could not calculate their influence over the course in comparison with others, or that Turkey's noisy reaction to the coup was aimed at a domestic, regional or international audience instead of aiming to have real influence on the ground.

Upon examination, three democratic countries took the coup in Egypt seriously: Turkey, the US and Israel. Among these, Turkey considered its material interests to be at stake with the coup; on the other hand, Israel regarded the coup as a saviour of its security and strategic concerns. For the US, the coup was neither a total loss nor a total win as it was for Israel and Turkey, but the US was able to ascertain its material interests. As a result of the coup, 
the Turkish government lost a possible strong ally for regional cooperation in the future. Further, the Turkish government faced the risk of the developments triggering a similar course at home. Israel not only left behind its concerns about an Islamist administration in Egypt disrupting the peace treaty, helping Hamas and avoiding cooperation on Sinai, but Israel also reached stronger cooperation on these matters with the new administration. The US was assured of its material interests with regard to Egypt and Israel's peace and security cooperation against the rise of violent extremism by having a more stable counterpart in Egypt. In terms of normative motivations, Turkey focused on the illegitimacy of a coup, whereas the US focused on the illiberal policies of Morsi in line with its material motivations. Israel had no normative approach. Along with these dynamics, Turkey reacted and signalled negatively to the coup and used statements and symbolic actions to delegitimize the coup. Turkey also used diplomatic channels and financial tools in opposition. The US shyly signalled positively and hesitantly used financial tools. Israel avoided signalling at all, but supported the coup quietly. Thus, refraining from signalling in response to a coup does not always indicate indifference and lack of interest. This finding requires further research, and also has implications regarding Turkey's approach. The influence of Turkey was limited despite its exhaustive negative signalling. Thus, Turkey either could not calculate its impact on the matter or, rather than impacting on the ground, it played just for the audience.

\section{Disclosure statement}

No potential conflict of interest was reported by the author.

\section{Notes on contributor}

Before beginning his doctoral studies at Bilkent University's Department of Political Science, Yegin obtained a Master's Degree in American Politics at University of Cincinnati in Ohio, and a Bachelor's Degree in International Relations from Bilkent University in Ankara. Yegin has focused the majority of his research on American politics and Turkey's security issues with particular reference to the alliances, Turkey-US relations, NATO, US-led Military Coalitions, and Counterterrorism.

\section{Notes}

1. M. Shannon, C. Thyne, S. Hayden and A. Dugan, 'The international community's reaction to coups', Foreign Policy Analysis, 11(4), 2015, p. 365.

2. Ibid., pp. $366-368$

3. A. Sen, 'Democracy as a universal value', Journal of Democracy, 10(3), 1999, p. 8.

4. S. P. Huntington, The Third Wave: Democratization in the Late Twentieth Century, University of Oklahoma Press, Oklahoma, 1991.

5. M. McFaul, 'Democracy promotion as a world value', Washington Quarterly, 28(1), 2004, p. 148.

6. Shannon, Thyne, Hayden and Dugan, op. cit., pp. 366-368.

7. C. Thyne and J. Powell, 'Coup d'état or Coup d'autocracy? How coups impact democratization, 1950-2008' Foreign Policy Analysis, doi: 10.1111/fpa.12046, p. 3.

8. Ibid., p. 26. The study show evidence that even moderately negative reactions from an outside country decrease the lifetime of a coup-born regime by 60 per cent.

9. E. Gartzke, Signaling the Liberal Peace, University of California, San Diego, Unpublished Manuscript. 
10. T. J. Piccone, International Mechanisms for Protecting Democracy, Democracy Coalition Project, Washington, D.C., 2004, p. 8.

11. Shannon, Tyne, Hyden and Dugan, op. cit., p. 364.

12. Piccone, op. cit., p. 29.

13. M. Nikolay, 'Do economic sanctions destabilize country leaders', American Journal of Political Science, 49(3), 2005, pp. 564-576.

14. K. Gude, 'Case studies in collective response', in M. Halperin and M. Galic (eds), Protecting Democracy: International Responses, Lexington Books, Lanham, 2005, p. 78.

15. Ibid., p. 64.

16. Gude, op. cit., p. 89.

17. B. Riedel, 'Pakistan and terror: the eye of the storm', Annals of the American Academy of Political and Social Science, 618, 2008, p. 38.

18. T. Asad, 'Fear and the ruptured state: reflections on Egypt after Mubarak', Social Research: An International Quarterly, 79(2), 2012, p. 276.

19. B. K. Rutherford, Egypt After Mubarak: Liberalism, Islam, and Democracy in the Arab World, Princeton University Press, Princeton, 2013.

20. Ibid., pp. xii-xiii.

21. L. Sadiki, "Egypt: from "election first" to "SCAF first", Al Jazeera Opinion, 18 June 2012 $<$ http://www.aljazeera.com/indepth/opinion/2012/06/201261882355312597.html> (accessed 13 February 2015).

22. M. Ma'oz, 'The 'Arab Spring' and the new geo-strategic environment in the Middle East', Insight Turkey, 14(4), 2012, p. 17.

23. M. Lynch (ed.), The Arab Uprisings Explained: New Contentious Politics in The Middle East, Columbia University Press, New York, 2014, p. 22.

24. F. Gerges, 'What changes have taken place in US foreign policy towards Islamists?', Contemporary Arab Affairs, 6(2), 2013, pp. 189-197.

25. M. Chadburn, 'Obama: Egypt neither enemy nor ally', Reuters, 13 September, $2013<$ http:// www.reuters.com/article/2012/09/13/us-usa-obama-egypt-idUSBRE88C0S820120913> (accessed 15 February 2015).

26. P. Droz-Vincent, 'The military amidst uprisings and transitions in the Arab world', in F. Gerges (ed.), The New Middle East: Protest and Revolution in the Arab World, Cambridge University Press, New York, 2014, pp. 180-208.

27. O. Housden, 'Egypt: coup détat or revolution protected?', RUSI Journal, 158(5), 2013, pp. 73-74.

28. O. B. Dinçer, B. Nur. Ozguler and M. Hecan, Ortadoğu'nun Kayıp İttifakı: Türkiye ve Mısır [The Missing Alliance of the Middle East: Turkey and Egypt] USAK Publications, Ankara, 2016, p. 37.

29. M. Sabry, 'Egypt's military steps in, issues ultimatum”, Al-Monitor, 1 July $2013<$ http://www. al-monitor.com/pulse/originals/2013/07/egyptian-military-threatens-intervention-followingprotests.html\#> (accessed 15 February 2015).

30. 'President Mohamed Morsi rejects Egypt army's ultimatum, as ministers resign', Daily Telegraph, 2 July, $2013<\mathrm{http}$ //www.telegraph.co.uk/news/worldnews/africaandindianocean/ egypt/10154074/President-Mohamed-Morsi-rejects-Egypt-armys-ultimatum-as-ministersresign.html> (accessed 15 February 2015).

31. Human Rights Watch World Report 2014/Egypt, <http://www.hrw.org/world-report/2014/ country-chapters/egypt $>$ (accessed 16 February 2015).

32. 'Egypt sentences Muslim Brotherhood leader and 182 followers to death', Guardian, 21 June $2014<$ http://www.theguardian.com/world/2014/jun/21/egypt-sentences-muslimbrotherhood-death $>$ (accessed 16 February 2015).

33. A. Davutoğlu, 'The three major earthquakes in the international system and Turkey', International Spectator, 48(2), 2013, p. 11.

34. P. Elman, 'Turkey's policy towards Egypt and its deepening isolation in the East Mediterranean', PISM Bulletin, No. 25 (757), 3 March 2015. 
35. B. Ayata, 'Turkish foreign policy in a changing Arab World', Journal of European Integration, 37(1), 2015, p. 109.

36. SETA, '2013'te Türkiye' [Turkey in 2013], Analysis No. 74, 2014, p. 123.

37. M. B. Altunış1k, 'Turkey as an "emerging donor" and the Arab uprisings', Mediterranean Politics, 19(3), 2014, pp. 341-342.

38. 'Yüksek Düzeyli İşbirliği Mekanizmaları', [High Level Cooperation Mechanisms], T.C. Başbakanlık Kamu Diplomasisi Koordinatörlüğ̈̈, [Republic of Turkey Prime Ministry Office of Public Diplomacy] <http://kdk.gov.tr/haber/yuksek-duzeyli-isbirligi-mekanizmalari/452> (accessed 20 February 2015).

39. 'Mısır-Türkiye İlişkilerinde Yeni Dönem', [A New Era in Turkey-Egypt Relations], Başbakanlık Yayın ve Enformasyon Genel Müdürlüğ̈̈ (BYEGM) <http://www.byegm.gov.tr/turkce/haber/ misir-trkye-lklernde-yen-dnem/6684> (accessed 20 February 2015).

40. Altunışık, op. cit., pp. 345-346.

41. Ayata, op. cit., p. 109.

42. M. Akyol, 'Turkey condemns Egypt's coup', Al-Monitor, 21 August $2013<$ http://www.almonitor.com/pulse/en/originals/2013/08/reasons-turkey-against-egypt-coup.html $>$ (accessed 21 February 2015).

43. K. Gursel, 'Coup in Egypt Strategic Loss for Erdogan', Al-Monitor, 5 July $2013<$ http://www. al-monitor.com/pulse/originals/2013/07/egypt-coup-is-erdogan-loss.html> (accessed 21 February 2015).

44. Dinçer, op. cit., p. 29.

45. 'Mısır Türkiye ile Ticaret Anlaşmasını Uzatmıyor' [Egypt will not extend trade agreement with Turkey], Al Jazeera Turk, <http://www.aljazeera.com.tr/haber/misir-turkiye-ile-ticaretanlasmasini-uzatmiyor> (accessed 20 February 2015).

46. SETA, op. cit., p. 124.

47. Davutoğlu, op. cit., p. 7.

48. Z. Öniş, 'Turkey and Arab revolutions: boundaries of regional power influence in a turbulent Middle East', Mediterranean Politics, 19(2), 2014, p. 217.

49. L. Diamond, Developing Democracy: Toward Consolidation, Johns Hopkins University Press, Baltimore, 1999, pp. 8-11.

50. 'Başbakan Erdoğan’ın Mısır'da Darbe Açılklaması' [Prime Minister Erdoğan's statements on the coup in Egpyt], Bugün Newspaper, July 5, 2013, <http://www.bugun.com.tr/gundem/ ben-buna-sasiyorum-haberi/706735> (accessed 21 February 2015).

51. 'Başbakan'dan Misır Zirvesi' [Prime Minister's meeting on Egypt], Hürriyet, July 5, 2013], $<$ http://www.hurriyet.com.tr/gundem/23653019.asp> (accessed 21 February 2015).

52. O. B. Dinçer and M. Yegin, 'It is time for Turkey to fix its relations with Egypt', German Marshall Fund On Turkey Series, 13 February 2015.

53. Jonathon Burch, 'Turkish PM calls for U.N. Security Council to convene on Egypt', Reuters, 15 August 2013, <http://www.reuters.com/article/2013/08/15/us-egypt-protests-turkeyidUSBRE97E0C520130815> (accessed 21 February 2015).

54. 'Erdoğan: BM'de aynaya bakacak yüz kalmadı' [Erdoğan: UN cannot look to mirror], BBC Türkçe, 17 August 2003, <http://www.bbc.co.uk/turkce/haberler/2013/08/130817_erdogan_ misir > (accessed 21 February 2015).

55. 'Turkey recalls ambassador in Cairo for consultations, Egypt reciprocates', Hurriyet Daily News, 15 August 2013], <http://www.hurriyetdailynews.com/turkey-recalls-ambassador-in-cairofor-consultations-egypt-reciprocates.aspx?pageID $=238 \& \mathrm{nID}=52642 \& \mathrm{NewsCat} I \mathrm{D}=338$ > (accessed 22 February 2015).

56. Altunişık, op. cit., p. 343.

57. 'Misır Savaş1, Hürriyet, 19 August 2013, <http://www.hurriyet.com.tr/gundem/24545062.asp> (accessed 22 February 2015); Yalçın Bayer, 'Günah Keçisi', Hürriyet, 21 August 2013. <http:// www.hurriyet.com.tr/yazarlar/24559984.asp> (accessed 22 February 2015).

58. Dinçer, op. cit., pp. 59-60.

59. G. Bahgat and R. Sharp, 'Prospects for a new US strategic orientation in the Middle East', Mediterranean Quarterly, 25(3), 2014, p. 33. 
60. S. Hamid and P. Mandaville, 'A coup too far: the case for U.S. priorities in Egypt', Brookings Doha Center Policy Briefing, September 2013, p. 2.

61. M. Dunne, 'A U.S. strategy toward Egypt under Sisi', 5 June 2014, <http://carnegieendowment. org/2014/06/05/u.s.-strategy-toward-egypt-under-sisi > (accessed 22 February 2015).

62. 'Vladimir Putin gains popularity in Egypt', TASS Russian News Agency, 27 July 2013, <http:// tass.ru/en/middle-east-and-north-africa/697801> (accessed 22 February 2015).

63. 'Assault on U.S. consulate in Benghazi leaves 4 dead, including U.S. Ambassador Christopher Stevens', CBS News, 12 September 2012. <http://www.cbsnews.com/news/assault-on-usconsulate-in-benghazi-leaves-4-dead-including-us-ambassador-j-christopher-stevens/> (accessed 23 February 2015).

64. 'Review of the terrorist attacks on U.S. Facilities in Benghazi Libya', Senate Select Committee on Intelligence, US Senate $113^{\text {th }}$ Congress, 11-12 September 2012 together with additional views 15 January 2015.

65. D. Huber, 'A pragmatic actor: the US response to the Arab Spring', Journal of European Integration, 37(1), 2015, p. 6.

66. Baghat and Sharp, op. cit., p. 33.

67. T. C. Wittes, 'Reported suspension of U.S. aid to Egypt a short-term measure', Brookings, 9 October 2013, <http://www.brookings.edu/blogs/up-front/posts/2013/10/09-us-egypt-aidwittes $>$ (accessed 23 February 2015).

68. S. Fabbrini and A. Yossef, 'Obama's wavering: US foreign policy on the Egyptian crisis, 201113', Contemporary Arab Affairs, 8(1), 2015, pp. 65-80.

69. 'U.S. gets it wrong on Egypt again', CNN, 25 January 2013, <http://edition.cnn.com/2013/01/24/ opinion/schneider-egypt/> (accessed 23 February 2015).

70. 'Statement by President Barack Obama on Egypt', The White House Office of Press Secretary, 3 July 2013, <https://www.whitehouse.gov/the-press-office/2013/07/03/statement-presidentbarack-obama-egypt $>$ (Accessed 16 July 2016).

71. 'Violence in Egypt', Secretary of State John Kerry's Press Statement, 6 July 2013, <http://www. state.gov/secretary/remarks/2013/07/211574.htm> (accessed 24 February 2015).

72. 'Egypt is still not a coup in Washington', BBC, 18 July 2013, <http://www.bbc.com/news/ world-us-canada-23351997> (accessed 24 February 2015).

73. For detailed info: the FY12 State Department and Foreign Operations Appropriations Law, Section 7008.

74. H. LaFrachi, 'Obama cut to Egypt aid could further weaken US influence in Mideast', Christian Science Monitor, 9 October 2013 <http://www.csmonitor.com/USA/Foreign-Policy/2013/1009/ Obama-cut-to-Egypt-aid-could-further-weaken-US-influence-in-Mideast> (accessed 24 February 2015).

75. Hamid and Mandaville, op. cit., pp. 1-4.

76. Wittes op. cit.

77. Huber, op. cit., p. 69.

78. S. Greval, 'The logic of partially suspending aid to Egypt', Washington Post, 12 October 2013, $<$ http://www.washingtonpost.com/blogs/monkey-cage/wp/2013/10/12/the-logic-of-partiallysuspending-aid-to-egypt/> (accessed 24 February 2015).

79. S. Hamid, 'Why did we suspend aid to Egypt, again?', The Atlantic, 13 November 2013, <http:// www.theatlantic.com/international/archive/2013/11/why-did-we-suspend-aid-to-egyptagain/281465/> (accessed 24 February 2015).

80. 'US unlocks the military aid to Egypt, backing President Sisi', BBC News, 22 June $2014<$ http:// www.bbc.com/news/world-middle-east-27961933> (accessed 24 February 2015).

81. S. Brom, 'Egypt after Morsi's victory in the presidential elections', Strategic Assesment, 15(2), 2012, p. 19.

82. C. Jones and B. M. Edwards, 'Missing the "devils" we knew? Israel and political Islam amid the Arab awakening', International Affairs, 89(2), p. 406.

83. D. Byman, 'Israel's pessimist view of Arab Spring', Washington Quarterly, 34(2), 2011, p. 123.

84. A. Susser, 'Egypt after Morsi's ouster: democracy without democrats', Tel Aviv Notes, 7(3), pp. 1-4, August 2013. 
85. Brom, op. cit., p. 21.

86. M. A. Heller, 'The uprisings in the Arab World and their ramifications for Israel', Strategic Assessment, 15(2), 2012, pp. 89; Amichai Magen, 'Comparative assessment of Israel's foreign policy response to the Arab Spring', Journal of European Integration, 37(1), 2015, p. 119.

87. E. Inbar, 'Israel's national security amidst unrest in the Arab world', Washington Quarterly, 35(3), 2012, p. 60.

88. 'Egyptians embrace revolt leaders, religious parties and military, as well', Pew Research Center/ Global Attitudes Project Report, 25 April 2011, <http://www.pewglobal.org/files/2011/04/ Pew-Global-Attitudes-Egypt-Report-FINAL-April-25-2011.pdf> (accessed 23 February 2015).

89. Z. Bar'el, 'Israel's take on Arab Spring may undo peace with Egypt', Haaretz, 30 November 2011, http://www.haaretz.com/print-edition/opinion/israel-s-take-on-arab-spring-mayundo-peace-with-egypt-1.398578 (accessed 25 February 2015).

90. E. Kam, 'The election of Abd al-Fattah el-Sisi as President of Egypt', INSS Insight, No. 557, 3 June 2014.

91. B. Friedman, 'Israel, Hamas and "the Egypt we were waiting for", Tel Aviv Notes, 6(22), November 2012, pp. 1-6.

92. Ibid.

93. E. Dickstein, 'A new role for Egypt: Sisi's government and the Arab-Israeli conflict', Harvard International Review, 36(2), January 2015.

94. S. Perry, 'Al-Sisi is not Israel's friend, he's a partner', Ynet News, 13 August 2014, <http://www. ynetnews.com/articles/0,7340,L-4557901,00.html> (accessed 25 February 2015); Dickstein, op. cit.

95. Inbar, op. cit., p. 67.

96. D. Hiro, 'Egyptian coup splits Middle East', Yale Global, 11 July $2011<$ http://yaleglobal.yale. edu/content/egyptian-coup-splits-middle-east> (accessed 26 February 2015).

97. J. Rudoren, 'Israel escalating efforts to shape allies' strategy', New York Times, 18 August 2015, <http://www.nytimes.com/2013/08/19/world/middleeast/israel-puts-more-urgencyon-shaping-allies-actions.html> (accessed 26 February 2015).

98. Magen, op. cit., p. 127.

99. 'Israel lobbying U.S., EU to support Egypt's military government', JTA, 19 August 2013, $<$ http://www.jta.org/2013/08/19/news-opinion/israel-middle-east/israel-lobbying-u-s-e-uto-support-egypts-military-government $>$ (accessed 26 February 2015). 